\title{
Introduction
}

\section{Literature of the Thirties: Region and Genre}

\author{
MARY JOANNOU (Guest Editor)
}

The second special issue on the literature of the thirties follows on from an earlier edition of Critical Survey which brought together new critical writings on the period (volume 10, number 3, 1988). The first four essays selected are responses to regionalism and identity and the last two to the issues raised by the relationships of gender and generic fiction. Simon Featherstone analyses how two popular artistes, Gracie Fields (the 'mill girl') and Max Miller ('the cheeky chappie') achieved success in an entertainment industry that was changing rapidly in response to technological and cultural pressures. Their stardom depended on the dialogues between regional and national identities as part of a national cultural dynamic during a decade in which mass popular forms reconstituted the older regional and local traditions of dialogue and performance. Steven Matthews sees Auden's injunction to 'Consider this and in our time' as a 'clarion call to a particular, post-The Waste Land, form of modernity'. Focusing on Scottish and Irish writers (Louis MacNeice, Sorley Maclean, Grassic Gibbon et al.) Matthews argues that the temporality of some thirties' writing aligns it closely with the emergent nationalisms familiar in recent postcolonial theory.

Morag Shiach is also concerned with regional diversity and modernity in Grassic Gibbon's A Scot's Quair trilogy and shows how Gibbon connects the temporalities of labour and historical change in the North-East of Scotland to the philosophical and political discourses of his time. Shiach links his writing to the interrogation of labour and its relations to selfhood in the work of George Sorel, Henri Bergson and D.H. Lawrence. Ayako Yoshino analyses the village pageant which was not a long-established English tradition but a 'contemporary and highly political form of theatre that had been "invented" less than four decades before' Virginia Woolf's deployment of it in Between the Acts. 
Yoshino discusses how Woolf's description of the pageant in her final novel resists the dominant nationalistic discourses of the time and represents an alternative vision of community.

The last two essays in this issue are concerned with examples of generic fiction; the detective novel and the historical novel. Gill Plain's essay on Margery Allingham argues for the recognition of the heterogeneity and complexity of the crime fiction in the thirties which is lost in the "homogenising generalisations that lump Christie, Allingham, Sayers and Marsh together as the "Golden Age" queens of crime'. Plain grapples with the paradoxes of gender in Allingham's fiction and sees her detective hero, Albert Campion as a 'fascinating precursor of contemporary efforts to destabilise or displace the detective's authority'. Finally, Diana Wallace draws attention to the importance of the thirties as a turning point in the development of the historical novel and its close association with women writers in this decade (Daphne Du Maurier, Georgette Heyer, Phyllis Bentley, Rose Macaulay, Naomi Mitchison, Sylvia Townsend Walker, etc). Wallace divides historical novels into four categories; 'the present as history', 'anti-Fascist novels', 'historical romances', and 'histories of the defeated' which she argues offer a kind of "wpardon" or rather a belated justice to the female "defeated" of the past'. 